\title{
Pharmacognostical Exploration of Saccharum officinarum
}

\author{
Dr. Pooja Semwal ${ }^{1 *}$, Dr. Ranjana Jai Singh ${ }^{2}$, Amit Kumar ${ }^{3} \&$ Jitender K Malik $^{3}$ \\ ${ }^{1}$ Smt.Manjira Devi Ayurvedic Medical College and Hospital-Uttarkashi, India \\ ${ }^{2}$ Om Ayurvedic Medical College Hospital and Research Center-Roorkee (Haridwar), India \\ ${ }^{3}$ Smt.Manjira Devi Shikshan and Prashikshan Institute Hitanu Dhanari- Uttarkashi, India
}

\begin{abstract}
DOI: $10.36348 /$ sijtcm.2021.v04i04.003
| Received: 08.03.2021 | Accepted: 22.04.2021 | Published: 30.04.2021

*Corresponding author: Pooja Semwal
\end{abstract}

\section{Abstract}

The selection proper raw materials in the production of herbal formulation standardization plays essential role. Sugarcane (Saccharum officinarum) is the most exclusively cultivated and India is the second largest producer country next to Brazil. It has been used as a sweetening agent for past era and also chiefly in the form of refined sugar. The present study was focused on preliminary pharmacognostic and phytochemical investigations for determining and establishing the identity, purity and quality of the plants. This will provide with an appropriate guidance for future exploration. The plant was subjected to determination of various physicochemical parameters including ash values (total ash, water soluble ash) and extractive values (alcohol soluble extractive, water soluble extractive). The powdered crude drug was extracted successively with various solvents with increasing polarity and further the extracts were subjected to phytochemical screening for the identification of various phytoconstituents. More over the fingerprint profile of Saccharum officinarum was established using thin layer chromatography (TLC) methods. The results of the TLC profiling of the extract confirm about the presence of various phytochemicals.

Keywords: Saccharum officinarum, Microscopy, Phytochemical investigations \& TLC profiling.

Copyright $\odot 2021$ The Author(s): This is an open-access article distributed under the terms of the Creative Commons Attribution 4.0 International License (CC BY-NC 4.0) which permits unrestricted use, distribution, and reproduction in any medium for non-commercial use provided the original author and source are credited.

\section{INTRODUCTION}

Pharmacological potential of medicinal plants is often known as a result of millennia of trial and error but they have to be carefully investigated if we wish to develop new drug that meet the criteria of modern treatment [1]. Medicinal plants are of great implication to the health of individuals and communities. India is well known as the "Emporium of Medicinal Plants". Due to their great importance, demand of medicinal plants has increased numerous folds [2]. Saccharum officinarum (Family-Poaceae) generally known as Sugarcane, Noblecane is broadly cultivated throughout tropic and subtropic regions. Saccharum is consequent from the Greek word 'Sakcharon,' which means sugar (sucrose).It is used as a folk medicine and also used as an antidote, antivenomous, antiseptic, bactericide, cardio-tonic, demulcent, intoxicant, diuretic, laxative, pectoral, refrigerant, and stomachic. It is a folk remedy for arthritis, bedsores, boils, cancer, colds, cough, diarrhoea, dysentery, eyes, fever, hiccups, inflammation, laryngitis, opacity, skin, sores, sore throat, spleen, tumors, and wounds [3].

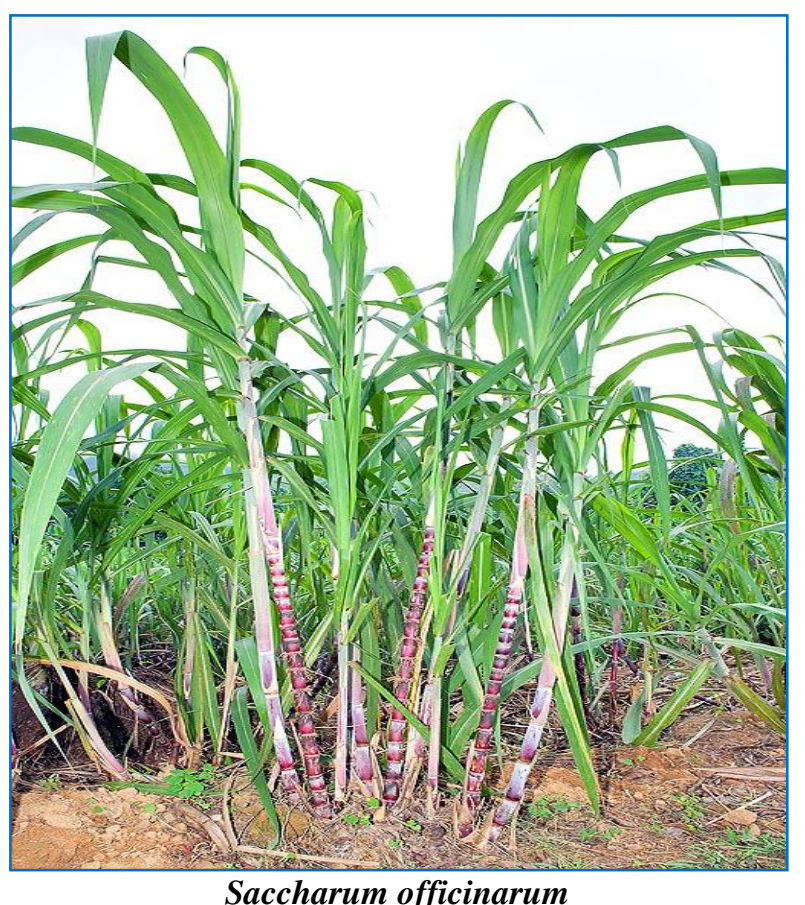

Saccharum officinarum 
The Ayurvedic Pharmacopoeia of India [4]

\begin{tabular}{|l|l|l|}
\hline Synonyms & Properties and action & Therapeutic uses \\
\hline Sans & Rasa -Madhur & Raktpitta,Mutrakrichcha, Ojoksay, Nasa \\
Dirghcchada & Guna-Sara, guru, snigdha & raktshsava, Grahni,Pandu, Ksataja Kasa, \\
Bhurirasa, & Vipaka -Madhura & Visarpa \\
Gudmul & Karma -Bramhana, vrsya, vatshamak, & \\
Asipatra & kaphakara, pittahar, mutrala, Balya. & \\
Tmarasa & & \\
Hindi - Ganna- & & \\
Ikh & \multicolumn{2}{|l|}{} \\
\hline $\begin{array}{l}\text { Important } \\
\text { formulation }\end{array}$ & Trinpanchmool kwath, Sukumar ghrit \& Brahma rasayan. \\
\hline
\end{tabular}

\section{MATERIALS AND METHODS Collection}

The sample of Specimen of Ikshu (Saccharum officinarum) was collected from Dehradun Uttrakhand in the last month of May.

Date of Collection: 5/12/2015 (Haridwar)

\section{Authentication}

The plant was authentication was done Botanical Survey of India (BSI), Dehradun.

\section{Microscopic Study}

Microscopic study of crude drugs is another aid of Pharmacognosy which can be helpful in the process of standardization of medicinal plants. This study can be helpful in identifying genuine drug by their known histological characters through Transverse section (T.S.) or Longitudinal Section (L.S.) or Radial Longitudinal Section (R.L.S.) or Tangential Longitudinal Section (T.L.S.) and Powder microscopy which can help in evaluation of different constituents by using different staining reagents. Specimens were soaked in water or other sovents depending upon the hardness of the sample and transverse sections were taken using sharp razor blades. Few microscopic sections were cut by Microtome sectioning. Numerous temporary and permanent mounts of the microscopical sections of the specimen were made and examined microscopically. Different staining reagents were applied on transverse sections so as to differentiate between different cell wall components.

\section{Preliminary Physiochemical Screening of Plant Extracts [5-9]}

\section{Determination of solvent extractive values}

\section{Determination of water soluble extractive value:}

$5 \mathrm{~g}$ of the air-dried drug, coarsely powdered were macerated with $100 \mathrm{ml}$ of water in closed flask for 24 hours, shaking frequently during the first 6 hours and allow standing for 18 hours. It was filtered rapidly taking precaution against loss of water, then the filtrate was evaporated $25 \mathrm{ml}$ of the filtrate to dryness in a tared flat-bottomed shallow dish, and dried at $105^{\circ} \mathrm{C}$ then weighed. The percentage of water-soluble extractive with reference to the air dried was calculated.

\section{Determination of alcohol soluble extractive value:}

$5 \mathrm{gm}$ of the air dried and coarsely powdered drug was macerated with $100 \mathrm{ml}$ of ethanol of the specific strength in a closed flask for 24 hours, shaking frequently during the first 6 hours and allow standing for 18 hours. There after filter rapidly taking precaution against loss of ethanol. Evaporate $25 \mathrm{ml}$ of the filtrate to dryness in a tared flat bottomed shallow dish, dry at $105^{\circ} \mathrm{c}$ and weigh. The percentage of ethanol soluble extractive with reference to the air dried drug has to be calculated.

\section{Determination of moisture content:}

Moisture is an inevitable component of crude drugs, which must be eliminated as far as practicable. Method of determination of moisture content include the loss on drying, the test for loss on drying determines both water and volatile matter in the crude drug. It can be carried out either by heating at $100^{\circ} \mathrm{C}-105^{\circ} \mathrm{C}$ or in a dessicator over phosphorous pentoxide under atmospheric or reduced pressure at room temperature for specific period of time.

\section{Ash value:}

Ash value is helpful in determining the quality and purity of a crude drug, especially in the powdered form. On incineration, crude drugs normally leave an ash usually consisting of carbonates, phosphates and silicates of sodium, potassium, calcium and magnesium. The total ash of a crude drug reflects the care taken in its preparation. A higher limit of acid-insoluble ash is imposed, especially in case where silica may be present or when the calcium oxalate content of the drug is very high.

Total ash value: 
Weighed accurately about 2 to $3 \mathrm{~g}$ of the powdered drug in a tared silica crucible. Incinerated at a temperature not exceeding $450{ }^{0} \mathrm{C}$ for $4 \mathrm{hr}$, until free from carbon, cooled and weighed. The percentage of ash with reference to air-dried was calculated following formula.

$$
\begin{array}{ll}
\% \text { Total ash value }=\quad \begin{array}{l}
\text { Wt. of total ash } \\
\text { Wt. of crude drugs }
\end{array} \times 100
\end{array}
$$

\section{Water soluble ash value:}

Boiled the ash with $25 \mathrm{ml}$ of water. Filtered and collected the insoluble matter on an ash less filter paper, washed with hot water and ignited in a tared crucible at a temperature not exceeding $450{ }^{\circ} \mathrm{C}$ for $4 \mathrm{hr}$. Cooled in a desiccator and weighed. Substrate the weight of insoluble matter from the total weight of ash. The difference in weight represented weight of water soluble ash. Calculated the percentage of water soluble ash with reference to the air- dried drug by using the following formula.

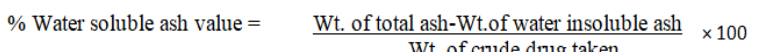
Wt. of crude drug taken

\section{Acid insoluble ash value:}

Boiled the ash for $5 \mathrm{~min}$ with $25 \mathrm{ml}$ of $2 \mathrm{M}$ HCL. Filtered and collected the insoluble matter on an ash less filter paper, washed with hot water and ignited in a tared crucible at a temperature not exceeding $450^{\circ}$ $\mathrm{C}$ for $4 \mathrm{~h}$. cooled in a desiccator and weighed. Calculated the percentage of acid insoluble ash with reference to the air -dried drug was calculated by using following formula,

$$
\% \text { Acid insoluble ash value }=\quad \frac{\text { Wt. of acid insoluble ash }}{\text { Wt. of crude drug taken }} \times 100
$$

\section{Preliminary qualitative test}

The various extract of S.officunarum was subjected to preliminary qualitative phytochemical investigation. The various tests and reagent used are given below;

\section{Alkaloids \\ Preparation of test solution: The test solution was prepared by dissolving extracts in the dilute hydrochloric acid.}

Mayer' test: The acidic test solution with Mayer's reagent (Potassium Mercuric iodide) gave cream colored precipitate.

Hager's test: The acidic test solution with Hager's reagent (Saturated picric acid solution) gave yellow precipitate.

Dragendorff's test: The acidic solution with Dragendorff's reagent (Potassium bismuth iodide) showed reddish brown precipitate.
Wagner's test: The acidic test solution treated with Wagner's reagent (Iodine in potassium iodide) gave brown precipitate.

Tannic acid test: The acidic test solution treated with Tannic acid gave buff colour precipitate.

Picrolonic acid test: Alkaloids gave yellow colour precipitate with picrolonic acid.

Amino acid:

Millon'test: To the test solution add about $2 \mathrm{ml}$ of millon's reagent white precipitate indicates presence of amino acid.

Ninhydrine test: To the test solution add Ninhydrine solution, boil, violet colour indicates presence of amino acid.

\section{Carbohydrates}

Preparation of test solution: The test solution was prepared by dissolving the test extracts with water. Then it was hydrolyzed with 1 volume of $1 \mathrm{~N}-\mathrm{HCL}$ and subjected to following chemical test.

Molisch's test: Test solution with few drops of Molisch's reagent and $2 \mathrm{ml}$ of conc. $\mathrm{H}_{2} \mathrm{So}_{4}$ added slowly from the sides of the test tubes. It showed a purple ring at the junction of two liquids.

Barfoed's test: $1 \mathrm{ml}$ of test solution is heated with $1 \mathrm{ml}$ of Barfoed, s reagent on water bath, if red cupric oxide is formed, monosaccharide is present. Disaccharides on prolong heating (about $10 \mathrm{~min}$.) may also cause reduction, owing to partial hydrolysis to monosaccharide.

Benedict's test: Test solution treated with Benedict' reagent and after boiling on water bath, it showed reddish brown precipitate.

Fehling's test: The test solution when heated with equal volume of Fehling's A and B solution, gave orange red precipitate, indicating the presence of reducing sugars

\section{Flavonoids}

The flavonoids are all structurally derived from the parent substance called flavones. The flavonoids occur in the free from as well as bound to sugars as glycosides. For this reason, when analyzing flavonoids it is usually better to examine the flavonoids in hydrolyzed plant extracts.

Preparation of test solution: To a small amount of extract added equal volume of $2 \mathrm{M} \mathrm{HCL}$ and heated in a test tube for 30 to $40 \mathrm{~min}$ at $100^{\circ} \mathrm{C}$. The cooled extract was filtered, and extracted with ethyl acetate The ethyl 
acetate was concentrated to dryness, and used to test for flavonoids.

Shinoda test: Test solution with few fragments of magnesium ribbon and conc. HCL showed pink to magenta red colour. To a small quantity of test solution when lead acetate solution was added, it formed yellow colored precipitate.

Alkaline reagent test: Test solution when treated with sodium hydroxide solution showed increase in the intensity of yellow colour, which becomes colorless on addition of few drops of dilute acid.

\section{Glycosides}

Preparation of test solution: The test solution was prepared by dissolving extract in the alcohol or hydroalcoholic solution.

\section{Test for Cardiac glycosides:}

Kedde' test: Add one drop of $90 \%$ alcohol and 2 drops of $2 \% 3,5$ - dinitro benzoic acid in 90\% alcohol. Make alkaline with $20 \%$ sodium hydroxide solution, purple colour is produced. The colour reaction with 3, 5dinitro benzoic acid depends on the presence of $\alpha, \beta$ unsaturated lactones in the aglycone.

Baljet's test: The test solution treated with sodium picrate gave yellow to orange colour.

Raymond's test: Test solution treated with hot methanolic alkali, violet colour is produced.

Bromine water test: Test solution dissolve in bromine water give yellow precipitate.

Keller-killani test for digitoxose: The test solution treated with few drops of Fecl3 solution and mixed, then $\mathrm{H}_{2} \mathrm{So}_{4}$ containing Fecl3 solution was added, it formed two layers. Lower layer reddish brown, upper layer turns bluish green.

Legal's test: Test solution when treated with pyridine (made alkaline by adding sodium nitroprusside solution) gave pink to red colour.

\section{Test for anthraquinone glycosides:}

Borntrager's test: Boiled powdered drug with $5 \mathrm{ml}$ of $10 \%$ sulphuric acid for five minutes. Filtered while hot, cooled the filtrate shaken gently with equal volume of benzene. Benzene layer was separated and then treated with half of its volume solution ammonia (10\%). Allowed to separate it. The ammonical layer acquired rose pink colour due to presence of anthraquinones.

\section{Proteins}

Preparation of test solution: The test solution was prepared by dissolving the extract in water.
Millon's test: Test solution was treated with millon's reagent and heated on a water bath. The proteins were stained red

Biuret test: Test solution was treated with $40 \%$ sodium hydroxide and dilute copper sulphate solution gave blue colour.

Xanthoproteic test: Test solution was treated with conc. $\mathrm{HNO}_{3}$ and boiled which gave yellow precipitate.

Modified Borntrager's test: C-glycosides of anthraquinones require more drastic conditions for hydrolysis. Hydrolysis of the drug was carried out with $5 \mathrm{ml}$ of dilute of HCL and $5 \mathrm{ml}$ of $5 \%$ solution of $\mathrm{Fecl}_{3}$. For hydrolyzed extract procedure was carried out as described under Borntrager's test.

\section{Test for steroids}

Preparation of test extract solution: The extract was refluxed separately with alcoholic solution of potassium hydroxide till complete saponification. The saponified extract was diluted with water and unsaponificable matter was extracted with diethyl ether. The ethereal extract was evaporated and the residue (saponificable matter) was subjected to the following test by dissolving the residue in the chloroform.

Salkowski test: To the test extract solution add few drops of conc. $\mathrm{H}_{2} \mathrm{SO}_{4}$ shaken and allowed to stand, lower layer turned red indicating the presence of steroids.

Libermann - Burchard test: The test solution treated with few drops of acetic anhydride and mixed, when conc. $\mathrm{H}_{2} \mathrm{SO}_{4}$ was added from the sides of the test tubes, it showed a brown ring at the junction of the two layers and the upper layers turned green. Added few drops of concentrated $\mathrm{H}_{2} \mathrm{SO}_{4}$. Blue colour appeared.

Sulphur test: Sulphur test when added in to the test solution, it sank it.

\section{Tannins and phenol compound}

To 2-3 ml of alcoholic or aqueous extract, added few drops of following reagents.

5\% Fecl $_{3}$ solution: Deep blue- black colour.

Lead acetate solution: White precipitate.

Bromine water: Discoloration of bromine water

Acetic acid solution: Red colour solution.

Dilute iodine solution: Transient red colour

One drop of $\mathrm{NH}_{4} \mathrm{OH}$, excess $10 \% \mathrm{AGNO}_{3}$ solution. Heated for $20 \mathrm{~min}$ in boiling water bath. White precipitate was observed, then dark silver mirror deposited on wall of test tube. 
T.L.C. plate coated with $0.25 \mathrm{~mm}$ layer of silica gel $\mathrm{GF}_{254}$ with fluorescent indicator, (Mercks) were used. (Each plate dimension is $10 \mathrm{~cm}$ long and $2 \mathrm{~cm}$ width).

\section{Triterpenoids}

Preparation of test extract solution: The test extract solution was prepared by dissolving extract in the chloroform.

Salkowski test: Few drops of concentrated sulphuric acid were added to the test solution, shaken and on standing lower layer turned golden yellow.

Microbiological determination tests [10-11]

Total viable aerobic count (TVC): Detection of the anti-bacterial activity of the test drug, the total viable aerobic count (TVC) of the test drug was carried out, as specified in the test procedure, using plate count. Pretreatment of the test drug Depending on the nature of the herbal drug sample used, it was dissolved using a suitable method and any antimicrobial property present in the sample was eliminated by dilution or neutralization. Buffered Sodium Chloride-Peptone Solution, pH 7.0 was used to dilute the test sample.

\section{Plate count for bacteria and fungi}

\section{For bacteria:}

$1 \mathrm{ml}$ of the pretreated test sample was added to about 15 $\mathrm{ml}$ of the liquefied casein-soybean digest agar in a petridish of $90 \mathrm{~mm}$ diameter at a temperature not exceeding 45 0C. Alternatively the test sample was spread on the surface of the solidified medium. Two dishes were prepared with the same dilution, they were inverted and incubated at 30-350C for 48-72 h, unless a more reliable count was obtained in a short period of time. The number of colonies so formed was counted and the results were calculated using the plates with the largest number of colonies, up to a maximum of 300 .

\section{For fungi:}

$1 \mathrm{ml}$ of the pretreated test sample was added to about 15 $\mathrm{ml}$ of the liquefied Sabered glucose agar with antibiotics in a petridish of $90 \mathrm{~mm}$ diameter at a temperature not exceeding $45^{\circ} \mathrm{C}$. Alternatively the test sample was spread on the surface of the solidified medium. Two dishes were prepared with the same dilution; they were inverted and incubated at $20-250 \mathrm{C}$ for 5 days, unless a more reliable count was obtained in a short period of time. The number of colonies so formed was counted and the results were calculated using the plates with not more than 100 colonies.

\section{Aflatoxins}

The test for determination of the aflatoxins was carried out using LCMS-Ms.

\section{TLC analysis for different Phytochemicals} Activation of pre-coated Silica gel $\mathbf{G 6 0 F}_{\mathbf{2 5 4}}$
Dry in hot oven at $105^{\circ} \mathrm{C}$ for one to two hour. Solvent system: Toluene, Ethyl Acetate (7:3)

Sample: Alcoholic Extract of test sample

Visualization: p-Anisaldehyde - sulfuric acid Reagent.

\section{RESULT AND DISCUSSION}

Sugarcane is used either as a single drug or in combination with some other plant materials as per literature in the Ayurvedic system of medicine. As folk medicine used sugarcane juice recommended for diuretic property. It is consideration that typical use of sugarcane juice will keep the urinary flow clear and fast, which will further help the kidneys to perform their function properly ${ }^{12-14}$. The roots and stem are medicinally useful, they are emollient, cardiotonic and useful in haematemesis, anemia and erysipelas. The collected drug were studied organoleptically with naked eye $\&$ magnifying lens, with the help of different Organoleptic features i.e. Colour, Odour, Taste, and Appearance were recorded(table-1). T.S of root showed single layered epidermis, sclerenchymatous cells, cortex, parenchymatous cells \& endodermis. The powder microscopic characteristics study revealed the presence of tannins; cutin \& lignins (table-2). Various physiochemical parameters were studied and result was tabulated in the table 3 . The extractive value was found to be $15.83 \% \mathrm{w} / \mathrm{w} \%$ (Alcohol Extractive Value) and $13.14 \%$ w/w (Aqueous Extractive Value).The phytochemical screening(table-4) revealed the presence of the various phytochemical in sequential order Aqueous extract > Alcoholic extract whereas the Pet.ether extract showed only presence of glycoside . As per WHO guideline of quality control of Herbal plants, the heavy metals analysis, total bacterial count and alfatoxins detection studies were carried out. The result was tabulated in the table 5-7. In Chromatographic study, TLC (table- 8) study showed the presence of phenol, sugars, steroids and terpenes nature of chemical constituents in all genuine samples and $\mathrm{R}_{\mathrm{f}}$ value of Saccharum officinarum were $0.83 \&$ 0.94 .

\section{CONCLUSION}

The present study deals with macroscopic, powder microscopic, phytochemical analysis and TLC fingerprinting. These studied will make available referentially information for correct identification and for standardization. This study also gives support to in the assessing of adulteration and substitution in market sample of the plant. 
Table-1: Macroscopic \& Organoleptic characteristics

\begin{tabular}{|l|l|}
\hline Macroscopic & Saccharum officinarum \\
\hline $\begin{array}{l}\text { Drug occur in form of rootstock with attached yellowish brown stem portion ,having } 10 \\
\text { to15cm.long numerous grey to blackish brown fibrous roots,jointed more or loss } \\
\text { cylindrical, } 2 \text { to } 2.5 \mathrm{~cm} \text {. thick and varying in length, brough ,fracture, splindary odour } \\
\text { and taste not distinct. }\end{array}$ \\
\hline Appearance & Fibrous \\
\hline Colour & Grey to blackish brown \\
\hline Odour & No specific odour \\
\hline Taste & No specific taste \\
\hline
\end{tabular}

Table-2: Powder Microscopy

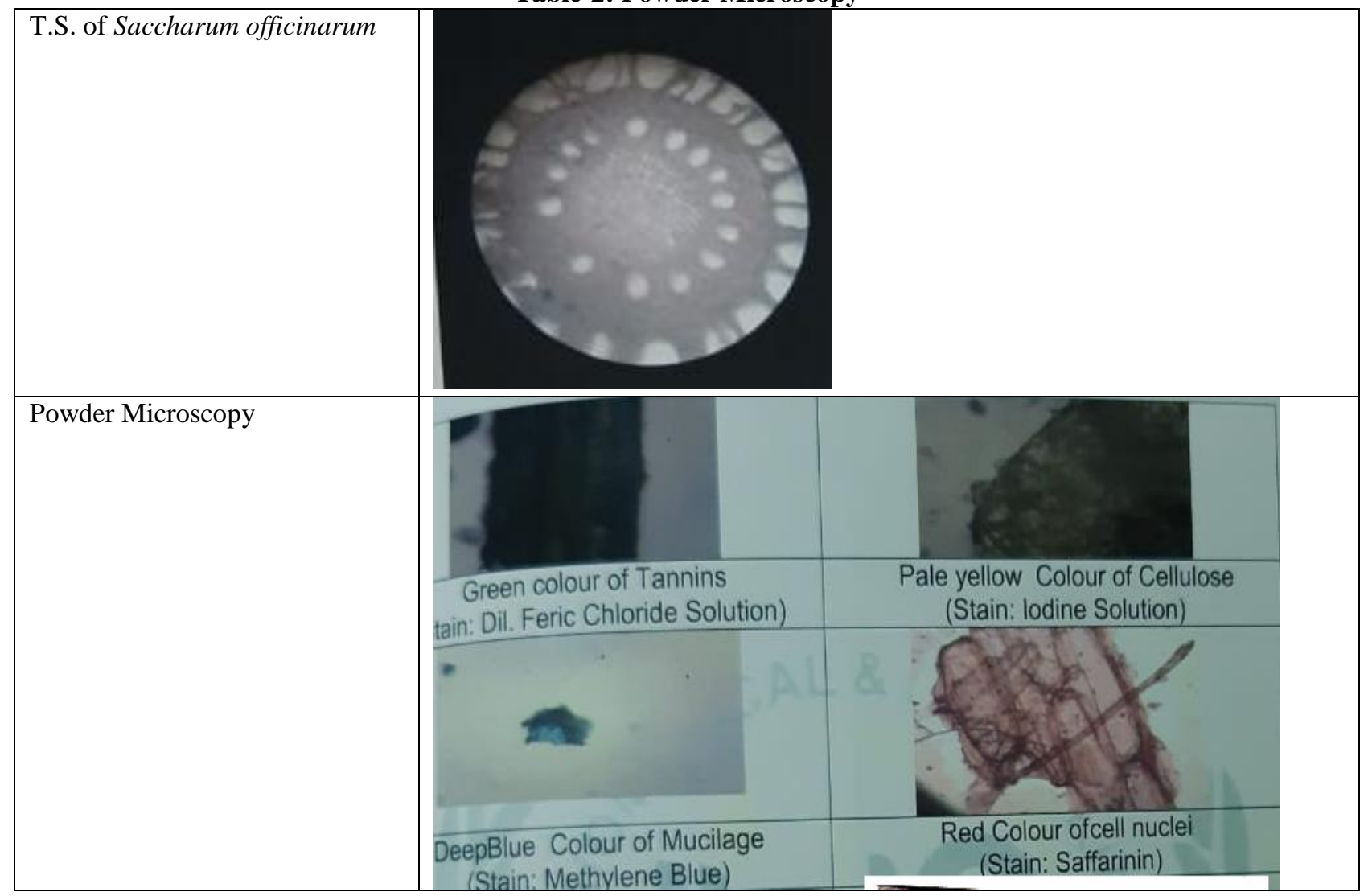




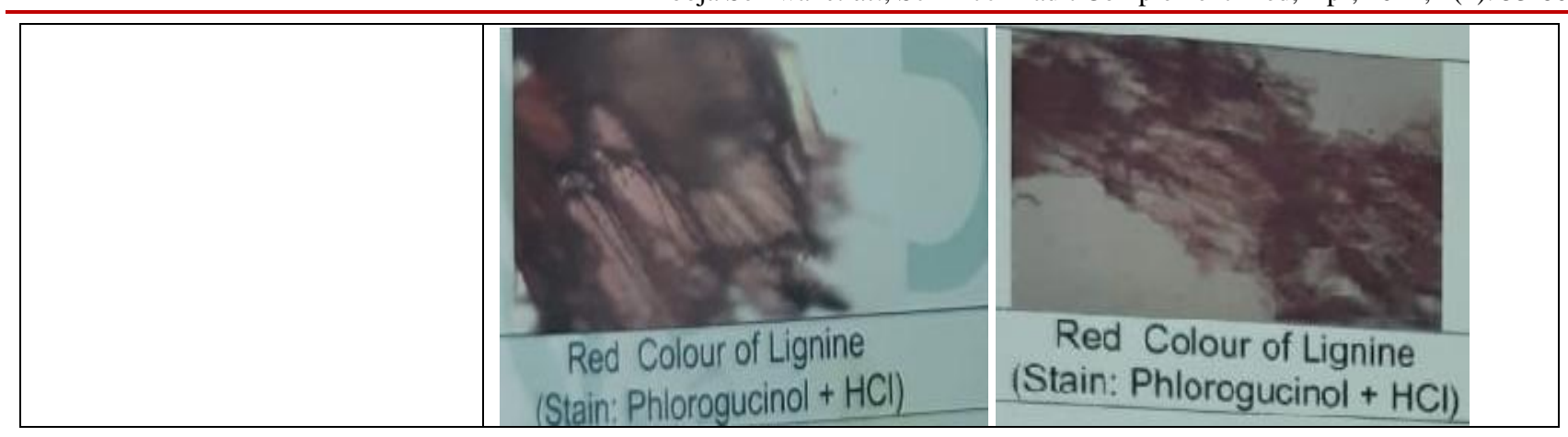

Table-3: Physiochemical study of Parameters

\begin{tabular}{|l|l|l|}
\hline S.No & Tests & Saccharum officinarum \\
\hline 1 & Moisture content & $4.65 \% \mathrm{v} / \mathrm{w}$ \\
\hline 2 & $\mathrm{pH}$ & 6.1 \\
\hline 3 & Alcohol Extractive Value & $15.83 \% \mathrm{w} / \mathrm{w}$ \\
\hline 4 & Aqueous Extractive Value & $13.14 \% \mathrm{w} / \mathrm{w}$ \\
\hline 5. & Pet.ether Extractive value & $6.42 \% \mathrm{w} / \mathrm{w}$ \\
\hline 6 & Total Ash & $12.24 \% \mathrm{w} / \mathrm{w}$ \\
\hline 7 & Acid Insoluble Ash & $3.67 \% \mathrm{w} / \mathrm{w}$ \\
\hline 8 & Water Soluble Ash & $7.43 \% \mathrm{w} / \mathrm{w}$ \\
\hline
\end{tabular}

Table-4: Results of preliminary phytochemical analysis

\begin{tabular}{|c|c|c|c|c|}
\hline \multirow[t]{2}{*}{ Sr. No. } & \multirow[t]{2}{*}{ Name of the Test } & \multicolumn{3}{|c|}{\begin{tabular}{|l|l|} 
& Observation \\
\end{tabular}} \\
\hline & & Aqueous Extract & Alcoholic Extract & Pet.ether Extract \\
\hline 1 & $\begin{array}{l}\text { Tests for sterols } \\
\text { Salkowski's Test } \\
\text { Libermann Burchard's Test }\end{array}$ & $\begin{array}{l}+ \\
+\end{array}$ & 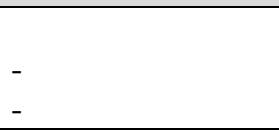 & 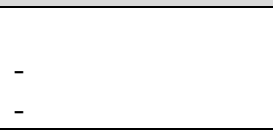 \\
\hline 2 & $\begin{array}{l}\text { Test for glycosides } \\
\text { Baljet's Test } \\
\text { Brontrager Test }\end{array}$ & $\begin{array}{l}+ \\
+\end{array}$ & $\begin{array}{l}+ \\
+\end{array}$ & $\begin{array}{l}+ \\
-\end{array}$ \\
\hline 3 & $\begin{array}{l}\text { Tests for saponins } \\
\text { Foam Test }\end{array}$ & + & - & - \\
\hline 4 & $\begin{array}{l}\text { Test for carbohydrates } \\
\text { Molish's Test } \\
\text { Barfoed's Test } \\
\text { Benedict's Test }\end{array}$ & $\begin{array}{l}+ \\
+ \\
+\end{array}$ & $\begin{array}{l}+ \\
- \\
+\end{array}$ & $\begin{array}{l}- \\
- \\
-\end{array}$ \\
\hline 5 & $\begin{array}{l}\text { Tests for alkaloids } \\
\text { Mayer's Test. } \\
\text { Wagner's Test. } \\
\text { Dragendorff's Test }\end{array}$ & $\begin{array}{l}+ \\
+ \\
-\end{array}$ & $\begin{array}{l}- \\
+ \\
+\end{array}$ & $\begin{array}{l}- \\
- \\
-\end{array}$ \\
\hline 6 & $\begin{array}{l}\text { Tests for flavonoids } \\
\text { Ferric chloride Test. } \\
\text { Shinoda Test. } \\
\text { Alkaline Reagent Test. } \\
\text { Lead Acetate Test. }\end{array}$ & $\begin{array}{l}+ \\
+ \\
+ \\
+\end{array}$ & $\begin{array}{l}+ \\
+ \\
+ \\
+\end{array}$ & $\begin{array}{l}- \\
- \\
- \\
-\end{array}$ \\
\hline 7 & $\begin{array}{l}\text { Tests for tannins } \\
\text { Ferric chloride Test. } \\
\text { Gelatin Test }\end{array}$ & $\begin{array}{l}+ \\
+\end{array}$ & - & - \\
\hline 8 & $\begin{array}{l}\text { Test for amino acid and protein } \\
\text { Biurete test }\end{array}$ & + & + & - \\
\hline
\end{tabular}


Table-5: HEAVY METAL ANALYSIS

\begin{tabular}{|l|l|l|l|}
\hline S.No. & Heavy metal & Saccharum officinarum (S1) & Permissible limit \\
\hline 1 & Lead & Not Detected & $\mathbf{1 0 p p m}$ \\
\hline 2 & Arsenic & Not Detected & $\mathbf{3 p p m}$ \\
\hline 3 & Cadmium & Not Detected & $\mathbf{0 . 3 p p m}$ \\
\hline 4 & Mercury & Not Detected & $\mathbf{1 p p m}$ \\
\hline
\end{tabular}

Table-6: TOTAL BACTERIAL COUNT

\begin{tabular}{|l|l|l|l|}
\hline S. No. & Analysis & Saccharum officinarum (S1) & Permissible limit \\
\hline 1 & Total Aerobic Microbial count & $\begin{array}{l}10000 \\
\text { cfu/gm }\end{array}$ & $\begin{array}{l}100000 \\
\text { cfu/gm }\end{array}$ \\
\hline 2 & Total Yeast \& Mould count & $\begin{array}{l}<10 \\
\text { cfu/gm }\end{array}$ & $\begin{array}{l}1000 \\
\text { cfu/gm }\end{array}$ \\
\hline
\end{tabular}

Table-7: TEST FOR AFLATOXINS

\begin{tabular}{|l|l|l|l|}
\hline S. No. & Test for Aflatoxins & Saccharum officinarum $($ S1) & Permissible limit \\
\hline $\mathbf{1}$ & Aflatoxin B1 & Absent & $\mathbf{0 . 5 p p m}$ \\
\hline $\mathbf{2}$ & Aflatoxin B2 & Absent & $\mathbf{0 . 1 p p m}$ \\
\hline $\mathbf{3}$ & Aflatoxin G1 & Absent & $\mathbf{0 . 5 p p m}$ \\
\hline $\mathbf{4}$ & Aflatoxin G2 & Absent & $\mathbf{0 . 1 p p m}$ \\
\hline
\end{tabular}

Table-8: TLC Fingerprinting

\begin{tabular}{|l|l|}
\hline Solvent system: Toluene, Ethyl Acetate (7:3) & \\
Sample: Alcoholic Extract of test sample & \\
Visualization: p-Anisaldehyde - sulfuric acid Reagent. & \\
& \\
& \\
\hline $\mathbf{R}_{\mathbf{f}}$ value & \\
\hline
\end{tabular}

\section{REFERENCE}

1. Malik, J.K., Soni, S.(2019). Recent updates on Phytoceuticals used in Pancreatitis. Asian Journal of Medical and Health Research. 4(07).

2. Himesh, S., Akhilesh, S.(2012). Recent updates on the genus Coleus: A Review. Asian J Pharm Clin Res., 5(1), 12.

3. Duke J.A., (1981). Atchley Approximate analysis. In: Christie, BR. The handbook of plant science in agriculture. CRC Press, Inc. Boca Raton,FL, 80-82.

4. The Ayurvedic Pharmacopoeia of India, Part-I, Vol-4 Ministry of Health and Family Welfare, Government of India, New Delhi, Controller of Publication Civil Lines, 1st Edition, Print : 2001. 88,89 .

5. Mukharjee, P. K. (2002) Quality control of herbal drugs- and approach to evaluation of botanicals $31^{\text {st }}$ edition. New Delhi, Business Horizons Pharmaceuticals. Publications.183-197.
6. Khandelwal, K. R. (1996) Practical Pharmacognosy. $\quad 3^{\text {rd }}$ edition. Pune: Nirali Prakashan. 165

7. Himesh, S., Govind, N., S.S. Patel, K,. Mishra, A.K,. (2011).Singhai.Pharmacognostic studies of the Leaves of Syzgium cumini Linn. Int. Journal of Research in Pharmaceutical and Biomedical Sciences. 2(2), 1-3.

8. Soni, H., SharanPatel, S., Mishra, K., Nayak, G., Singhai, A. K., \& Pathak, A. K. (2011). Preliminary pharmacognostical and phytochemical investigation of Tamarindus indica L. seed. Int. J. Res. Phytochem. Pharmacol, 1(2), 1-5.

9. Soni, H., Nayak, G., Mishra, K., Singahi, A. K., \& Pathak, A. K. (2010). Pharmacognostic and Phytochemical Evalution of Leaves of Coleus aromaticus. International Journal of Pharmacology and Biological Sciences, 4(4), 71. 
10. Anonymous. WHO guidelines for assessing quality of herbal medicine with reference to contaminants and residues, (2007) World Health Organization Geneva. 14-15.

11. Khan, Z. J., Khan, N. A., Naseem, I., \& Nami, S. A. A. (2017). Determination of heavy metals, aflatoxins, microbial loads and pesticides residue in sehjana (Moringa oleifera lam) fruits/pods. Interna. Resea. J. Pharm, 8(10), 203-207.

12. Singh, A., Lal, U. R., Mukhtar, H. M., Singh, P. S., Shah, G., \& Dhawan, R. K. (2015). Phytochemical profile of sugarcane and its potential health aspects. Pharmacognosy reviews, 9(17), 45.

13. Soni, H., \& Malik, J. K. (2021). PhytoPharmacological Potential of Zizyphus jujube: A Review. Sch Int J Biochem, 4(2), 1-5.

14. Soni, H., Nayak, G., Patel, S. S., Mishra, K., Singh, R. V., \& Singhai, A. K. (2011). Pharmacognostic studies of the leaves of Tinospora cordifolia. IJPI'SJ Pharm Herb Formul, 1(3). 